\title{
Correction to: Genetic response to nitrogen starvation in the aggressive Eucalyptus foliar pathogen Teratosphaeria destructans
}

\author{
Minette Havenga ${ }^{1,2}\left(\mathbb{D} \cdot\right.$ Brenda D. Wingfield $^{1}\left(\mathbb{D} \cdot\right.$ Michael J. Wingfield $^{1}\left(\mathbb{D} \cdot\right.$ Léanne L. Dreyer $^{3}\left(\mathbb{D} \cdot\right.$ Francois Roets $^{2}(1) \cdot$ \\ Janneke Aylward ${ }^{1,2}$ (1)
}

Published online: 17 October 2021

(c) Springer-Verlag GmbH Germany, part of Springer Nature 2021

\section{Correction to: Current Genetics \\ https://doi.org/10.1007/s00294-021-01208-w}

In the original publication of the article, it states the Accession number is pending at two locations. This has been corrected here.

1. Last line in Materials and Methods under the section "Identification and functional annotation of putative pathogenicity factors". It states: The annotated genome, including predicted proteins is now available on GenBank under the accession number: RIBY02000000.
2. Last line under Data availability it states: study is available on GenBank (https://www.ncbi.nlm.nih.gov/genba $\mathrm{nk} /$ ) under the accession number: RIBY02000000.

Publisher's Note Springer Nature remains neutral with regard to jurisdictional claims in published maps and institutional affiliations.

The original article can be found online at https://doi.org/10.1007/ s00294-021-01208-w.

Minette Havenga

havenga.minette@ fabi.up.ac.za

1 Department of Biochemistry, Genetics and Microbiology, Forestry and Agricultural Biotechnology Institute (FABI), University of Pretoria, Pretoria, South Africa

2 Department of Conservation Ecology and Entomology, Stellenbosch University, Stellenbosch, South Africa

3 Department of Botany and Zoology, Stellenbosch University, Stellenbosch, South Africa 